Jurnal At-Tibyan: Jurnal Ilmu Alqur'an dan Tafsir Volume 5 No. 1, Juni 2020 (h.120-137)

P ISSN 2442-594X | E ISSN 2579-5708

http://journal.iainlangsa.ac.id/index.php/tibyan

\title{
KONSEP WADRIBUHUNNA DALAM QS. AN-NIS Ā [4] : 34 STUDI KOMPARASI WAHBAH ZUHAILI DAN M. QURAISH SHIHAB
}

\author{
Wadribūhunna Concept in QS. An-Nisā [4] : 34; Comparative Study Wahbah Zuhaili \\ and Muhammad Quraish Shihab
}

\author{
Moh. Fauzan Fathollah \\ Ilmu al-Quran dan Tafsir UIN Sunan Ampel Surabaya \\ mohfauzan939@gmail.com

\begin{tabular}{|l|l|l|}
\hline \multicolumn{2}{|c|}{ DOI: 10.32505/tibyan. v5i1.1403 } \\
\hline Submitted: 27-01-2020 & Revised: 13-06-2020 & Accepted: 28-06-2020 \\
\hline
\end{tabular}

\begin{abstract}
Abstrsct
Nush $\overline{u z}$ is a wife's that disobedience to the husband. Nush $\bar{u} z$ 's wife to the husband mentioned in QS. An-Nisā [4] : 34. Indirectly in that verse also has been mentioned in tandem with a way to educate the wife of the nushüz. Many of the differences mentioned by the commentators to provide solutions regarding the wife who is nush $\bar{u} z$. But, what is at the heart of the settlement is the final method, wadribūhunna (hitting). The concept of wadribūhunna mentioned by Wahbah Zuhaili is to beat by not injuring his wife while the concept of wadribunna. Muhammad Quraish Shihab is to look at the situation between men and women today, which is equal, so hitting is not the last way, but the right way is to give a gesture that can provide subtle education to wives who are nushüz. However, the two commentators have the same goal of the meaning of wadribühunna, namely to apply the concept of islāh that exists in the area of distribution of each interpretation.
\end{abstract}

Keywords: Nushūz, wadribūhunna, Wahbah Zuhaili, M. Quraish Shihab.

\begin{abstract}
Abstrak
Nush $\bar{u} Z$ adalah ketidak patuhan istri terhadapp suami. Nushūz istri kepada suami yang telah disebutkan dalam QS. An-Nisa [4]: 34. Secara tidak langsung dalam ayat itu juga telah disebutkan secara beriringan cara untuk mendidik istri yang nushüz. Banyak perbedaan yang disebutkan para mufassir untuk memberikan solusi mengenai istri yang nushüz. Akan tetapi yang menjadi inti dari penyelesaian tersebut adalah cara terakhir, yaitu wadribühunna (memukul). Konsep wadribūhunna yang disebutkan oleh Wahbah Zuhaili adalah memukul dengan tidak mencederai istri sedangkan konsep wadribühunna Muhammad Quraish Shihab yaitu dengan melihat
\end{abstract}

Hak Cipta @ 2020. Dimiliki oleh Penulis, dipublikasikan oleh Jurnal At-Tibyan: Jurnal Ilmu Alqur'an dan Tafsir.

Artikel dengan akses terbuka. Lisensi: CC-BY

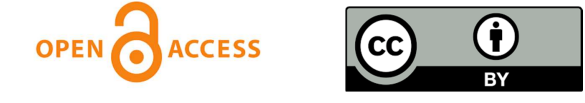


keadaan antara laki-laki dan perempuan saat ini, yaitu bersifat equal, sehingga memukul bukan cara terakhir, akan tetapi cara yang tepat adalah dengan memberikan isyarat yang dapat memberikan pendidikan halus kepada istri yang sedang nushüz. Akan tetapi, dari kedua mufassir tersebut memiliki tujuan yang sama dari makna wadribühunna yaitu untuk menerapkan konsep isslāh yang ada pada daerah sebaran tafsir masing-masing.

Kata Kunci: Nushūz, wadribūhunna, Wahbah Zuhaili, M. Quraish Shihab

\section{Pendahuluan}

Al-Quran merupakan kitab suci yang sempurna, al-Quran juga merupakan bacaan yang tidak ada pembandingnya. Dalam sejarah, tidak ada satu pun karya yang dapat menandingi kesempurnaaan al-Quran baik dari segi bahasa, ataupun nilai-nilai yang terkandung di dalamnya. Al-Quran juga merupakan bacaan yang paling banyak dibaca oleh orang-orang di dunia, baik yang berasal dari agama Islam atau yang berasal dari agama lain, baik yang mengerti atau tidak. Mereka membacanya dengan berbagai macam tujuan baik dengan tujuan untuk dihafal, dan diteliti serta direnungkan baik oleh anak-anak bahkan orang dewasa. ${ }^{1}$

Mengutip pendapat Abdul Mustaqim dalam bukunya Dinamika Sejarah Tafsir al-Quran, dikatakan bahwa sebagian ayat-ayat yang ada dalam al-Quran mengandung banyak makna atau penafsiran (yahtamilu al-wujuh al-ma'na) dan juga mengutip pendapat para pakar seperti Martin Whittingham yaitu satu kitab dengan banyak makna (one book many meaning), dan Muhammad Arkoun yang mengutip hadis riwayat $\mathrm{Abu}$ Darda, mengatakan bahwa: seseorang akan dikatakan benar paham terhadap al-Quran, sehingga orang tersebut dapat melihat berbagai wajah penafsiran yang banyak di dalamnya (lā yafqahu ar-rajulu kulla al-fiqhi hatta yara fi al-Quran wujūhan katsīran). ${ }^{2}$

Penafsiran terhadap al-Quran dilakukan oleh para ulama ahli tafsir untuk mendapatkan jawaban yang pas dari ayat-ayat yang ada ataupun dari persoalan. Banyak persoalan yang solusi akhir atau jawaban dari persoalan tersebut bersumber dari al-Quran. Seperti contoh persoalan dalam keluarga (suami-istri).

Apabila membahas tentang keluarga, berarti ada kaitannya dengan pernikahan. Dalam hubungan sebuah keluarga, pernikahan adalah ikatan lahir dan batin antara lakilaki dan perempuan sebagai suami-istri yang diikat dengan akad yang sangat kuat (mithāqan galiza) yang bertujuan untuk membina kehidupan rumah tangga yang

${ }^{1}$ M. Quraish Shihab, Wawasan al-Quran: "Tafsir Tematik Atas Pelbagai Persoalan Umat" (Bandung: Penerbit Mizan, 2013), 3.

${ }^{2}$ Abdul Mustaqim, Dinamika Sejarah Tafsir al-Quran: Studi Aliran-Aliran Tafsir dari Periode Klasik, Pertengahan, hingga Modern-Kontemporer (Yogyakarta: Pondok Pesantren LSQ ar-Rahmah, 2012), 10-11. 
(sakinah mawaddah wa rahmah). ${ }^{3}$ Maka dari itu, dengan hadirnya agama Islam dan alQuran sebagai kitab pedoman menjadi jawaban yang sangat tepat, khususnya dalam sosial.

Dalam kehidupan berumah tangga, keadaan (sakinah mawaddah wa rahmah) dapat dicapai dengan baik, apabila keadaan dalam keluarga (suami-istri) dapat bersama-sama menjalankan semua hak dan kewajiban dengan baik dan benar sesuai dengan aturan yang berlaku dalam kehidupan rumah tangga. ${ }^{4}$

Dalam kitab Fiqhu as-Sunnah, milik Sayyid Sābiq dijelaskan bahwa, hak dan kewajiban dalam keluarga (suami-istri) ada tiga, yaitu: hak istri atas suami, hak suami atas istri dan hak dalam kebersamaan. Dari ketiga hak tersebut adakalanya bersifat kebendaan, seperti: mahar dan nafkah, dan adakalanya bersifat kebatinan seperti: adil, saling memperlakukan dengan baik dan menggauli. ${ }^{5}$ Apabila hak dan kewajiban dalam keluarga sudah terlaksana, maka akan terbentuklah keluarga yang harmonis. Akan tetapi sebaliknya, apabila salah satu dari keluarga tersebut tidak saling memenuhi hak dan kewajibannya, maka akan mulai timbul konflik dan permasalahan dalam keluarga tersebut.

Dalam al-Quran dijelaskan bahwa konflik yang ada dalam keluarga disebut dengan nushüz. Secara umum nushūz bermakna perubahan yang terjadi pada keluarga, baik dari pihak suami ataupun istri. Tanda nushüz dari suami biasanya berubahnya sifat lemah lembutnya menjadi pribadi yang kasar bahkan dapat juga hilangnya rasa kasih dan sayang terhadap istri. Sedangkan, nush $\bar{u} z$ dari pihak istri ditandai dengan meninggalkan kewajiban sebagai seorang istri, seperti menentang terhadap suami, kasar, keluar rumah tanpa seizin dari suami atau bahkan enggan dalam berhubungan seks. Akan tetapi kebanyakan dalam al-Quran dan kitab-kitab fiqh menjelaskan tentang nushüz nya seorang istri kepada suami. ${ }^{6}$ Penjelasan tentang nushüz nya istri terdapat dalam QS. An-Nisā [4] : 34 yaitu:

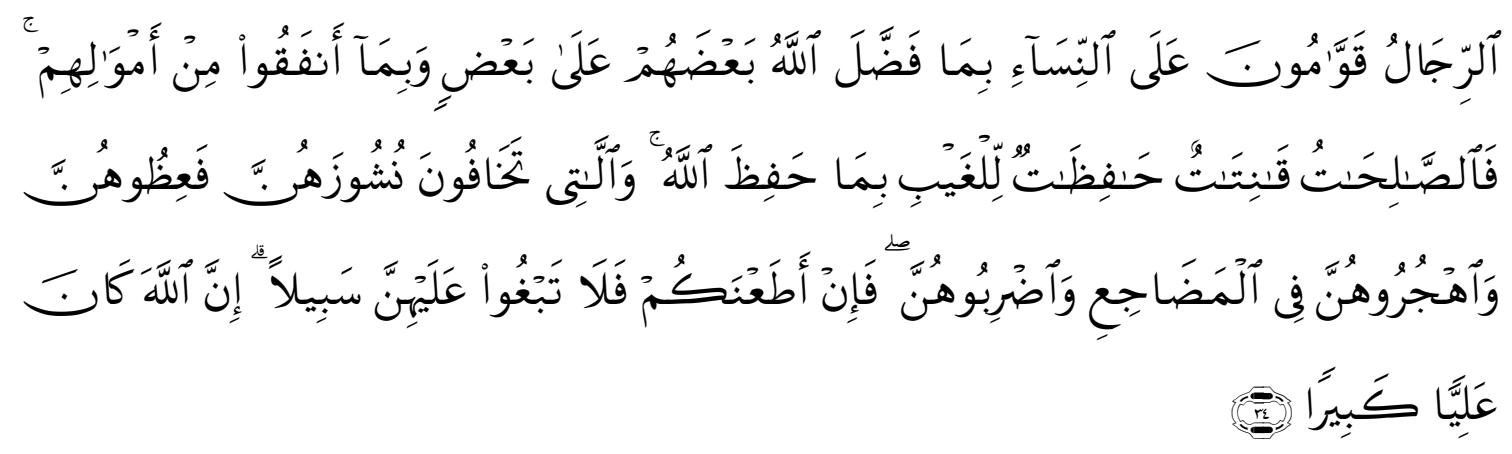

\footnotetext{
${ }^{3}$ Abdul Ghani Abdullah, Pengantar Kompilasi Hukum Islam Dalam Tata Hukum Indonesia, (Jakarta: Gema Insan Press, 1994) 78. Lihat juga dalam Kompilasi Hukum Islam (KHI), Pasal 2 dan 3. Sedangkan pada definisi perkawinan terdapat dalam UUD No. 1 Tahun 1974.

${ }^{4}$ Siti Musdah Mulia, Kemuliaan Perempuan dalam Islam (Jakarta: LBH-APIK, 2014), 59.

${ }^{5}$ Sayyid Sābiq, Fiqhu as-Sunnah, Jil. II (Madinah: al-Fath li I'lāmi al-‘Arabi, 1992), 298.

${ }^{6}$ Penjelasan ini lebih lengkapnya terdapat dalam Ensiklopedi Islam, dengan kode NAH-SYA. (Jakarta: Ichtiar Baru van Hoeve, 1993), 49-50. Penjelasan yang lainnya terdapat juga dalam Departemen Agama RI, al-Quran dan Terjemahannya (Surabaya: Putra Mahkota, 1990), 85.
} 
Artinya: "Laki-laki (suami) itu, pelindung bagi perempuan (istri). Karena Allah telah melebihkan sebagian mereka (laki-laki) atas sebagian yang lain (perempuan), dan karena mereka (laki-laki) telah memberikan nafkah dari hartanya. Maka, perempuan yang salihah adalah mereka yang taat (kepada Allah), dan menjaga diri mereka ketika (suaminya) tidak ada, karena Allah telah menjaga (mereka). Perempuan-perempuan yang kamu khawatirkan akan nushüz hendaklah kamu beri nasihat kepada mereka, tinggalkanlah mereka di tempat tidur (pisah ranjang), dan (kalau perlu) pukullah mereka. Tetapi jika mereka menaatimu, maka janganlah kamu mencari-cari alasan untuk menyusahkannya, sungguh Allah Maha Tinggi, Maha Besar”. (QS. An-Nisā $[4]: 34){ }^{7}$

Dalam penjelasan tafsir klasik dan pertengahan, ${ }^{8}$ ayat tersebut dijadikan sebagai bahan untuk menjustifikasi yang menggambarkan superioritas seorang laki-laki terhadap perempuan. Di antara para ulama yang menjadikannya yaitu: Ibn Katshir, alQurțūbi, Ibn Jarir at-T̄bari dan lainnya. Para ulama tersebut memaknai kata (الرجال) dengan arti laki-laki dan lawannya adalah kata (النساء) dengan arti wanita.9

Pendapat yang menggambarkan sebagai superioritas mungkin terjadi pada masa lalu, akan tetapi pada masa modern ini, semuanya antara laki-laki dan perempuan memiliki derajat dan kemampuan yang bisa dikatakan sepadan, karena tidak sedikit perempuan yang dapat menempati posisi penting baik di negara Indonesia ataupun di negara-negara yang mengangkat derajat wanita, seperti negara-negara yang ada di benua Eropa dan Amerika. ${ }^{10}$

Jika dilihat secara kebahasaan, arti dari QS. An-Nisā [4] : 34 ini, menjelaskan tentang nush $\bar{u} z$ nya istri, yaitu ketidak patuhan terhadap suami. Kata yang menunjukkan bahwa itu adalah istri pada lafadz (نشوزهن) yang berarti nushüz seorang istri. Kelanjutan pada potongan ayat ini merupakan jawaban yang harus dilakukan oleh suami, apabila istrinya melakukan nushūz yaitu (فظوهن) hendaklah kamu beri nasihat kepada mereka, (و الهروهن في المضاج) tinggalkanlah mereka di tempat tidur (pisah ranjang) ( kalau perlu) pukullah mereka.

Perlu diketahui bahwa pada ayat di atas merupakan kesatuan ayat yang akan dibahas dalam tulisan ini, akan tetapi yang menjadi inti dari pembahasan kali ini 84.

${ }^{7}$ Departemen Agama RI, Al-Quran dan Terjemah Bahasa Indonesia (Kudus: Menara Kudus, 2006),

${ }^{8}$ Tafsir Periode Klasik adalah tafsir yang muncul dan berkembang pada masa Rasulullah hingga muncul tafsir pada masa pembukuan (Abad I-II H). Tafsir Periode Pertengahan adalah tafsir yang muncul setelah periode klasik dan sebelum tafsir periode kontemporer. Penjelasan yang lebih lengkap dapat dilihat dalam buku milik Abdul Mustaqim, Madzahibut Tafsir Peta Metodologi Penafsiran alQuran Periode Klasik Hingga Kontemporer (Yogyakarta: Nun Pustaka, 2003), 33-118.

${ }^{9}$ Abdurrahman Kyai Demak, Kepemimpinan Wanita dalam Islam dalam al-Quran dan Isu Kontemporer (Yogyakarta: elSAQ Press, 2011), 340.

${ }^{10}$ Muslikhati, Feminisme dan Pemberdayaan Perempuan dalam Timbangan Islam, (Jakarta: Gema Insani, 2004), 20. 
adalah kalimat (و اضربوهن) Wadribūhunna. Pengambilan kalimat tersebut sebagai bahan kajian dengan banyak alasan, akan tetapi yang menjadi alasan utama adalah maraknya kekerasan dalam rumah tangga (KDRT) di Indonesia.

Metode yang digunakan dalam penelitian ini adalah metode kualitatif, dengan tujuan untuk mendapatkan pemahaman yang ada dalam QS. An-Nisā [4] : 34 secara detail. Sedangkan pada jenis penelitan dalam tulisan ini berbentuk kepustakaan (library research), yaitu suatu penelitian dengan cara mencari dan mengumpulkan data yang berkaitan dengan objek penelitian. Dalam hal ini, ada dua data yang digunakan sebagai bahan kajian yaitu, berupa buku-buku rujukan (printed materials), dan perpustakaan digital (digital materials) yang berupa ebook, pdf, dan al-Quran digital. Dari kedua data ini saling memberikan pemahaman dalam kajian, khususnya pada kajian ini.

Sedangkan dari teknik analisa datanya menggunakan metode deskriptif untuk dapat menggambarkan secara sistematis dan cermat. Sedangkan dalam metode penafsirannya, yang digunakan dalam penelitian ini adalah metode perbandingan (muqārin), yaitu suatu perbandingan baik dalam ayat-ayat al-Quran yang memiliki redaksi yang hampir sama, perbandingan ayat dan hadist șahih yang memiliki pertentangan dari segi makna, dan perbandingan pendapat mufassir dalam menafsirkan al-Quran. Dalam hal ini antara Wahbah Zuhaili dan M. Quraish Shihab tentang QS. An-Nisā [4] : 34.

\section{Redaksi Ayat}

Ayat yang menjadi penelitian merupakan pilihan yang disesuaikan dengan kejadian yang sedang aktual dan booming, seperti kekerasan dalam rumah tangga (KDRT), dan lainnya yang menjadi faktor penyebabnya. Ayat yang menjadi bahan dasar kajian yaitu pada QS. An-Nisā [4] : 34.

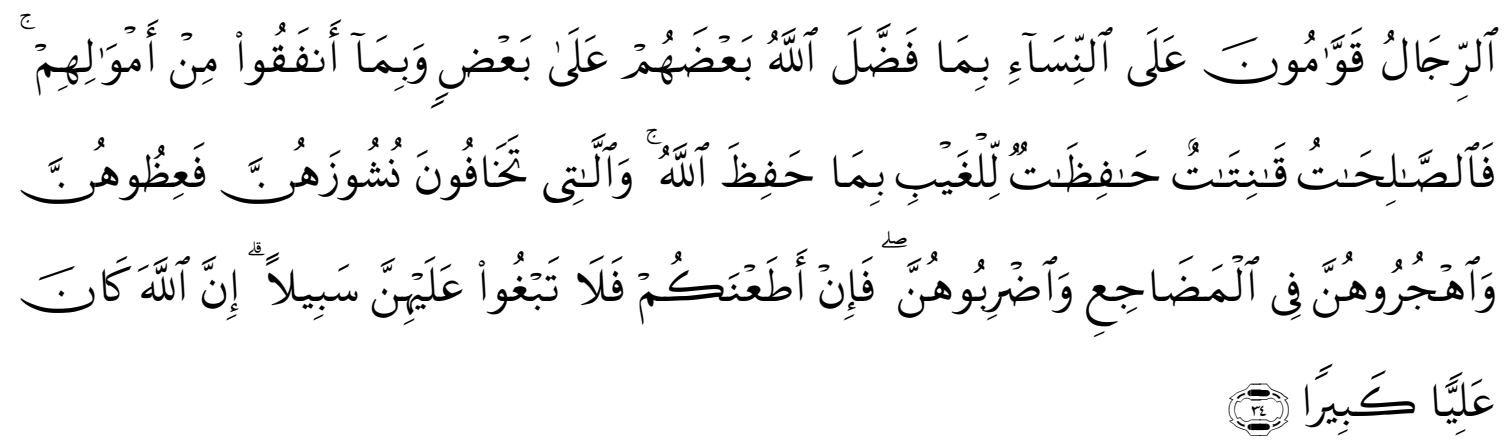

Artinya: "Laki-laki (suami) itu, pelindung bagi perempuan (istri). Karena Allah telah melebihkan sebagian mereka (laki-laki) atas sebagian yang lain (perempuan), dan karena mereka (laki-laki) telah memberikan nafkah dari hartanya. Maka, perempuan yang salihah adalah mereka yang taat (kepada Allah), dan menjaga diri mereka ketika (suaminya) tidak ada, karena Allah telah menjaga (mereka). Perempuan-perempuan yang kamu khawatirkan akan nushüz hendaklah kamu beri nasihat kepada mereka, tinggalkanlah mereka di 
tempat tidur (pisah ranjang), dan (kalau perlu) pukullah mereka. Tetapi jika mereka menaatimu, maka janganlah kamu mencari-cari alasan untuk menyusahkannya, sungguh Allah Maha Tinggi, Maha Besar”. (QS. An-Nisā [4] : 34).

Diambilnya ayat tersebut sebagai gambaran dan contoh pendidikan dalam keluarga. Secara tidak langsung al-Quran menjawab pertanyaan yang ada dalam satu surat tersebut dalam mendidik keluarga. Akan tetapi terdapat satu kalimat yang menjadi jalan terakhir bagi seorang suami dalam menjalankan kerukunan keluarga, yaitu dengan cara memukul sehingga dinamakan dengan kekerasan yang berbentuk fisik. Kalimat yang dimaksud adalah (و اضروهن), kalimat ini menurut sebagian ulama memiliki variasi arti, ada yang mengatakan memukul dan ada juga yang mengatakan pukulan mendidik.

Timbulnya perbedaan merupakan salah satu alasan dipilihnya ayat itu. Akan tetapi alasan yang utama adalah untuk memberikan gambaran dan ilmu secara tidak langsung dalam keluarga agar sama-sama saling mendukung, dan bagi keluarga yang mendapati istrinya sedang nushüz, jalan terakhir adalah dengan memukul. Cara yang dipakai oleh penulis untuk mendalami makna yang terselubung pada kalimat tersebut adalah dengan cara mengambil dua tokoh yang dianggap memiliki penafsiran yang berbeda, baik dikarenakan latar belakang, ataupun keyakinan dalam madhab yang berbeda ataupun daerah yang menjadi kajian masing-masing mufassir yaitu: $\mathrm{M}$. Quraish Shihab (Indonesia-Syafii) dan Wahbah Zuhaili (Mesir-Hanafi).

\section{Asbabun Nuzul}

(الرجال قوامون), berasal dari Ibn Abi Hatim dari Hasan al-Bașri berkata: Pada suatu ketika, datang seorang wanita menghadap Rasulullah SAW, untuk mengadukan permasalahannya yaitu, mukanya ditampar oleh suaminya. Kemudian Rasulullah SAW, bersabda: "suamimu itu harus dibalas (qiṣass)". Dengan sabda Rasulullah SAW tersebut, Allah SWT menurunkan ayat ke-34 dan 35, yang dengan tegas memberikan ketentuan bahwa bagi orang laki-laki (suami) ada hak untuk mendidik istrinya yang melakukan penyelewengan terhadap haknya sebagai istri. Setelah mendengar keterangan dalam ayat tersebut, wanita itu pulang dengan tidak menuntut qișăs kepada suaminya yang telah menamparnya. ${ }^{11}$

Pada riwayat yang lain, datanglah seorang wanita yang mengadukan masalahnya kepada Rasulullah SAW. Pada suatu ketika wanita itu ditampar mukanya oleh suaminya yang merupakan sahabat Anshar. Sedangkan maksud kedatangan wanita itu kepada Rasulullah SAW, untuk menuntut balas terhadap perbuatan suaminya. Rasulullah SAW, ketika itu mengabulkan permohonannya, sebab belum ada kejelasan

\footnotetext{
${ }^{11}$ HR. Ibn Abi Hatim dari Hasan al-Bașri, terdapat dalam, Ismāil Ibn Umar Ibn Kathsīir, Jamī alMasānid wa as-Sunan, Juz XIII, (Beirut: Dār Khudr, 1998), 398. Lihat juga pada Jalaluddin as-Suyūti, ad-Durru al-Manthūr fi Tafsīr bi al-Ma'thūr, Juz II, (Riyadh: Dār 'Alim al-Kutūb, 2015), 513.
} 
hukum dari Allah SWT. Sehubungan dengan kejadian itu Allah menurunkan ayat ke-34 dan 35 sebagai bentuk ketegasan tentang kewajiban hak suami untuk mendidik istrinya yang membangkang. Selain itu, Rasulullah SAW, dilarang memutuskan suatu perkara sebelum ayat al-Quran diturunkan. ${ }^{12}$ sebagaimana yang dilakukan dalam memberikan hukuman qiṣās terhadap suami atas gugatan istri tersebut yang terdapat dalam QS. Taha [20]: 114 yaitu:

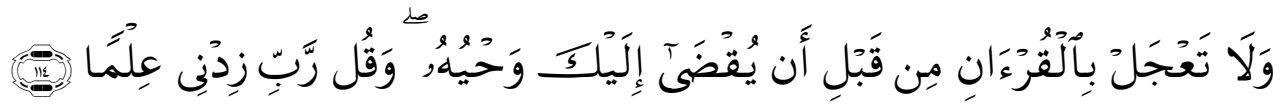

Artinya: "Dan janganlah kamu (Muhammad) tergesa-gesa dalam membaca al-Quran sebelum selesai diwahyukan kepadamu". (QS. Taha [20]: 114).

Dalam riwayat lainnya, dijelaskan bahwa suatu saat datanglah seorang laki-laki dari kalangan sahabat Anshar untuk menghadap Rasulullah SAW, bersama istrinya. Ketika itu, istrinya mengadu kepada Rasulullah SAW, "Wahai Rasulullah, suamiku telah memukul wajahku hingga terdapat bekas luka”. Kemudian Rasulullah SAW, bersabda "suamimu tidak ada hak untuk melakukan hal demikian, dia harus di-qiṣās. Dari kejadian tersebut, Allah SWT menurunkan ayat ke-34 dan 35 sebagai penjelasan hukum bahwa seorang suami berhak untuk mendidik istrinya. Dengan demikian hukum qiṣās yang dijatuhkan oleh Rasulullah SAW, itu gugur dan tidak jadi dilaksanakan. ${ }^{13}$

Ayat ini turun pada Saad Ibn Rabi' yang merupakan sahabat Anshar dan istrinya Habibah Binti Zaid Ibn Abi Zuhair dan keduanya berasal dari kalangan Anshar yang bertujuan untuk mengadukan kepada Rasulullah SAW, atas kejadian yang dilakukan suaminya yaitu menamparnya. Kemudian Rasulullah SAW, memintanya agar melakukan qiṣās kepada suaminya, tak berselang lama kemudian Rasulullah SAW, menyuruhnya kembali lagi dikarenakan malaikat Jibril mendatangi Rasulullah SAW, dan menurunkan ayat ini (QS. An-Nisā [4] : 34), kemudian Rasulullah SAW bersabda "kita menginginkan sesuatu dan Allah juga menginginkan sseuatu juga dan apa yang diinginkan Allah adalah yang baik" maka gugurlah qiṣass. ${ }^{14}$

\section{Munasabah}

Ayat-ayat sebelumnya membahas mengenai larangan iri hati terhadap seseorang yang memperoleh karunia yang lebih banyak dan lebih baik, kemudian menyuruh agar harta peninggalan diberikan kepada ahli waris yang berhak menerimanya menurut bagiannya masing-masing. Sedangkan pada ayat ini dijelaskan

\footnotetext{
${ }^{12}$ HR. Ibn Jarir dengan jalan yang sampai kepada Hasan dan juga bersumber dari Juraij dan asSa'di. Terdapat dalam, 'Ațiyah Ibn 'Ațiyah al-Ajhuri, Irsyād ar-Rahmān li Assāa an-Nuzūl, (Beirut: Dār Ibn Hazm, 2009), 199.

${ }^{13}$ HR. Ibn Mardawaih dan Ali Ibn Abi Talib. Lihat pada Abi Ja'far Muhammad Ibn Jarir at-Tabari, Tafsir at-Ṭabari Jāmiul Bayān 'an Ta’wīli āyi al-Quran, (Kairo: Dār-Hijr, 2001), 690-694.

${ }^{14}$ Imam Abi Hasan Ali Ibn Ahmad al-Wahidi, Asbāb Nuzūl al-Quran (Libanon: Dār-al-Kutūb alIlmiyah), 144-145.
} 
mengenai kewenangan suami sebagai pemimpin bagi perempuan (istri), dan keluarga, serta cara menyelesaikan perselisihan suami istri. ${ }^{15}$

Pada ayat selanjutnya menjelaskan mengenai kewajiban seseorang kepada Allah dan kewajiban terhadap sesama manusia. Kewajiban kepada Allah berupa ibadah dan mengabdi kepada-Nya dengan penuh ketaatan, kerendahan hati dengan merasakan kebenaran dan keagungan-Nya baik secara sembunyi-sembunyi dan terang-terangan. Sedangkan kewajiban kepada sesama manusia yaitu dengan cara menambahkan hal-hal yang positif baik dalam sosial kemasyarakatan atau keadaan individu (perbaikan diri pribadi). ${ }^{16}$

Allah menyebutkan mengenai sebab keutamaan dari seorang laki-laki (rijāt) terhadap perempuan (nis $\bar{a}$ ) yang telah dijelaskan pada bab warisan, bahwa laki-laki menempati dan memperoleh bagian lebih banyak dari perempuan. Pada bab itu Allah juga menjelaskan mengenai keutamaan sebagian di antara mereka terhadap sebagian yang lain. ${ }^{17}$

\section{Analisa Redaksi Ayat}

Redaksi ayat yang akan dibahas berkenaan dengan kehidupan sosial dalam keluarga yaitu antara suami dan istri. Dalam berkeluarga, suami istri harus hidup rukun dengan tujuan agar supaya menjadi keluarga yang sakinah mawaddah wa rahmah sehingga keturunan yang dihasilkan dapat melanjutkan nama baik keluarga. Akan tetapi tidak dapat dipungkiri dalam kehidupan berkeluarga ada sisi positif dan negatif, apabila yang terjadi pada sisi positif, maka dampak kepada masyarakat akan dilihat baik, sebaliknya jika sisi negatif karena tidak adanya kerukunan dalam keluarga maka label yang akan didapat pada keluarga itu adalah label yang berdampak pada keturunan dengan sebutan kelurga broken home. ${ }^{18}$

Apabila antara suami dan istri tidak ada yang mau mengalah terhadap konflik yang terjadi, maka dapat dikhawatirkan seorang istri akan ditalak oleh suami atau suami akan melakukan praktik kasar. Akan tetapi jika suami mengerti dengan syariat hukum Islam, maka akan menerapkan bagaimana cara menghadapi istri yang demikian.

Maka dari itu, fungsi, hak, dan kewajiban dalam setiap jenis kelamin juga disinggung dalam ayat ini, yaitu dengan menempatkan laki-laki sebagai pemimpin atau penanggung jawab (qawwām) atas perempuan (nisā). Karena itu, Allah memberikan kelebihan kepada suami karena kewajiban dalam membayar mahar, menafkahi keluarga dalam kehidupan berkeluarga. Sehingga diwajibkan dalam keluarga untuk saling mengerti dan memahami satu sama lain tanpa ada rasa iri hati.

\footnotetext{
${ }^{15}$ Kementerian Agama RI, al-Quran dan Tafsirnya, Jil. II. (Jakarta: Widya Cahaya, 2011), 162.

${ }^{16}$ Kementerian Agama RI, al-Quran dan Tafsirnya, 166.

${ }^{17}$ Wahbah Zuhaili, at-Tafsìr al-Munïr fi al-'Aqīdah wa as-Sharī'ati wa al-Manhaj, Juz. III. (Damaskus, Dār al-Fikr, 2009), 57.

${ }^{18}$ Waryono Abdul Ghafur, Menyingkap Rahasia al-Quran (Yogyakarta: eLSAQ Press, 2009), 399.
} 
Latar Belakang dan Komparasi Penafsiran Antara Wahbah Zuhaili dan M. Quraish Shihab serta Implementasinya

Penafsiran yang dilakukan oleh Wahbah Zuhaili dan M. Quraish Shihab menurut penulis dianggap berbeda, dikarenakan beberapa faktor yang menjadi latar belakang, di antaranya perbedaan dalam latar belakang keyakinan, pendidikan, metode penafsiran dan yang menjadi pokok perbedaan yaitu penerapan dalam tafsirnya. Jikalau M. Quraish Shihab daerah sebaran tafsirnya berlaku pada masyarakat Indonesia yang mayoritas bermadzhab Syafii sedangkan Wahbah Zuhaili sebaran tafsirnya berlaku pada masyarakat yang bermadzhab Hanafi yang berada di daerah Mesir.

Menurut hemat penulis, jika dilihat dalam dunia pendidikan, hal yang menyebabkan perbedaan penafsiran lainnya adalah M. Quraish Shihab menempuh pendidikan S1, S2, dan S3-nya diselesaikan di Al-Azhar Mesir. Sehingga, dalam pemikirannya didominasi oleh hal-hal yang berhubungan dengan pembaharuan, sebagaimana yang didengung-dengungkan oleh Muhammad Abduh, Rasyid Ridha, dan cendekiawan-cendekiawan muslim Mesir lainnya, baik dalam masalah keyakinan (aqīdah), ibadah (ubüdiyah), dan sosial kemasyarakatan (muämalah). Hal ini berbeda dengan Wahbah Zuhaili, meskipun Wahbah Zuhaili pernah juga mengenyam pendidikan di Al-Azhar, Mesir, akan tetapi tidak merubah pendiriannya terhadap masalah-masalah agama secara signifikan, terutama dalam bidang fiqh. Semua ini merupakan konsekuensi logis dari pribadi Wahbah Zuhaili yang dilahirkan, dididik, dan dibesarkan dalam lingkungan madzhab fiqh Hanafi. ${ }^{19}$

Selain itu, tidak menutup kemungkinan akan adanya perbedaan dalam penafsiran keduanya baik disebabkan oleh metodologi, ataupun kaidah yang digunakan dalam penafsirannya. Karena, menurut Alfatih Suryadilaga, seorang mufassir ketika ingin menafsirkan al-Quran harus memenuhi kaidah-kaidah tafsir yang sudah dirumuskan oleh ulama-ulama terdahulu. Tujuannya adalah untuk dapat menyingkap rahasia makna al-Quran secara maksimal baik dari segi makna, hukum, isi, dan petunjuk yang ada di al-Quran. ${ }^{20}$

Kaidah-kaidah yang biasa digunakan dalam menafsirkan al-Quran ada lima yaitu, pertama, menafsirkan al-Quran dengan al-Quran. Kedua, menafsirkan al-Quran dengan hadis Nabi. Ketiga, menafsirkan al-Quran dengan pendapat sahabat. Keempat, menafsirkan al-Quran dengan pendapat tabiin. Kelima, menafsirkan al-Quran dengan pendekatan kebahasaan. $^{21}$

Dalam at-Tafsir al-Munir karya Wahbah Zuhaili, pada pendahuluannya dijelaskan bahwa kaidah yang digunakan dalam tafsirnya adalah gabungan dari bi alMa'thür dan bi ar-Ra'yi. Pada kaidah bi al-Ma'thür lebih ditekankan pada hadis Nabi dan pendapat sahabat serta tabiin. Sedangkan pada bagian bi ar-Ra'yi, lebih ditekankan pada tiga aspek yaitu, pertama, penelitian yang mendalam dari kata atau lafad, asbāb

${ }^{19}$ Muhammad Ali Iyāzi, al-Mufassirūn Hayātuhum wa Manhajuhum (Teheran: Irshādul Islami, t.th), 688. Lihat dalam muqaddimah at-tafsir al-Munir karangan Wahbah Zuhaili.

${ }^{20}$ Alfatih Suryadilaga, Metodologi Ilmu Tafsir (Yogyakarta: Teras, 2005), 57.

${ }^{21}$ Ahmad Izzan, Metodologi Ilmu Tafsir (Bandung: Tafakur, 2007), 123. 
an-nuzūl, dan perbuatan yang pernah dilakukan para mujtahid dan ulama terdahulu untuk mencapai tujuannya. Kedua, menjaga kemurnian al-Quran dengan cara meneliti secara seksama terhadap bahasa al-Quran yaitu bahasa Arab. Ketiga, memilah pendapat dari berbagai tafsir yang memiliki keterkaitan dalam dalil hukum dan tujuantujuan dari hukum syariat. ${ }^{22}$

Sedangkan kaidah yang digunakan oleh M. Quraish Shihab tidak jauh berbeda dengan kaidah yang digunakan Wahbah Zuhaili, yaitu menafsirkan al-Quran dengan alQuran, menafsirkan al-Quran dengan hadis, menafsirkan al-Quran dengan pendapat sahabat, tabiin dan ulama, serta menafsirkan al-Quran dengan pendekatan kebahasaan. Akan tetapi pada aspek kebahasaan diberikan peluang yang cukup besar dengan tujuan kandungan dan tujuan dari ayat al-Quran yang ditafsirkan dapat disesuaikan dengan kondisi dan keadaan masyarakat khususnya Indonesia. ${ }^{23}$

Sebelum memasuki wilayah penafsiran alangkah baiknya jika mengetahui makna yang menjadi dasar bagi kedua mufasir di atas. Di antara kata yang menjadi dasar yaitu (الرجال). Dari kata ini banyak di antara mufassir mengartikan kata tersebut dengan makna para suami, dan juga ada yang mengartikan dengan pemimpin dikarenakan bersanding dengan lafad (قوامون). Kata selanjutnya yang menjadi topik sesuai dengan judul yaitu (إضرب), yang memiliki banyak makna, di antaranya bermakna

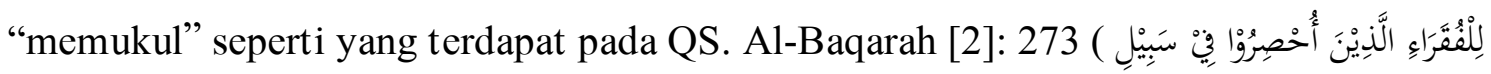

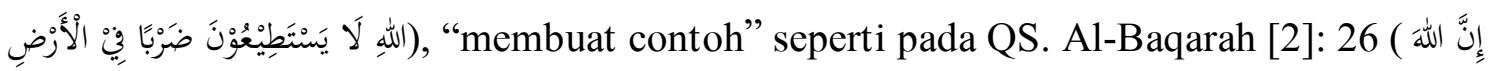

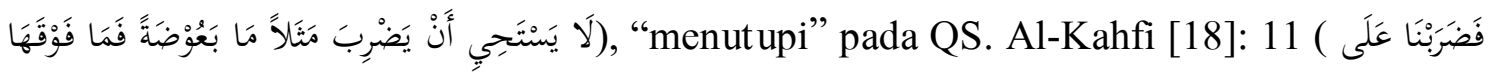
(أَذَفْمِم فيْه الْكَهْنِ سِنِيْنَ عَدَدًا

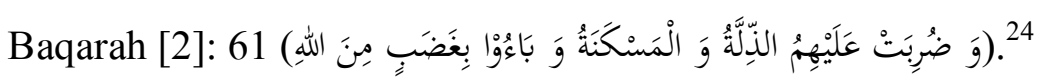

Kalimat dasar dari (ضرب) adalah yang makna umumnya adalah memukul. Merupakan cara terakhir mengobati penyakit istri yang nushüz, dan membangkang terhadap perintah suaminya adalah dengan memukul istri. Apabila dalam kehidupan rumah tangga suaminya sudah dikotori, dirusak kehormatannya, dan melakukan sesuatu atas kemauan pribadi yang melanggar syariat sehigga menyebabkan hancurnya kehidupan keluarga oleh istri, lantas apa yang harus diperbuat oleh pribadi suami ketika menghadapi keadaan seperti ini?

Al-Quran telah memberikan jalan keluar (problem solving) yang bersifat edukatif kepada suami terhadap istri, yaitu dengan sikap sabar, memberikan nasihat, dan tidur tidak seranjang dengannya. Apabila langkah-langkah ini tidak berhasil, maka ada cara lain yang harus ditempuh seorang suami, yaitu memukul dengan pukulan yang

\footnotetext{
${ }^{22}$ Wahbah Zuhaili, at-Tafsir al-Munir, fi al- 'Aqìdah wa as-Sharī' ati wa al-Manhaj, Juz I, 6.

${ }^{23}$ M. Quraish Shihab, Tafsir Al-Misbah: Pesan, Kesan dan Keserasian Al-Quran, vol II (Jakarta: Lentera Hati, 2002), xii.

${ }^{24} \mathrm{Abu}$ al-Qāsim al-Husain bin Muhammad, Al-Mufradāt fì Gharīb al-Quran (T.t: Nazār Musthafa al-Baz, t.th), 384 .
} 
tidak melukai istri untuk menghilangkan kesombongannya. Dilakukannya langkah ini tidak lain adalah untuk menghindari ke-mudarat-an yang lebih besar, yaitu dijatuhkannya talak kepada istri. Maka dari itu, apabila bertemu dua ke-muḍarat-an, maka diambil yang lebih kecil sifat muḍarat-nya, yaitu dengan mengambil langkah bijak dari al-Quran itu. Dikatakan dalam sebuah syair, "Alangkah baiknya bagi orang yang buta, diberitahukan kejelekannya." 25

Dalam menafsirkan ayat ini Wahbah Zuhaili memulai dengan berpendapat bahwa yang menyebabkan laki-laki menjadi pemimpin ada dua yaitu, pertama, adanya bukti fisik yang menyatakan bahwa laki-laki pemimpin yang mulia yang memiliki kekuatan dari segi fisik dan batin ditandai dengan kalimat (قوامون). Maka dari itu, lakilaki boleh dalam memperbanyak istri. Kedua, kewajiban memberikan nafkah (infaq), dan kebutuhan terhadap istri, serta memberikan mahar terhadap istri dengan tujuan

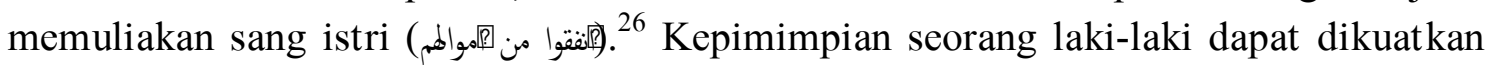
seperti yang terdapat dalam QS. Al-Baqarah [2]: 228 yaitu:

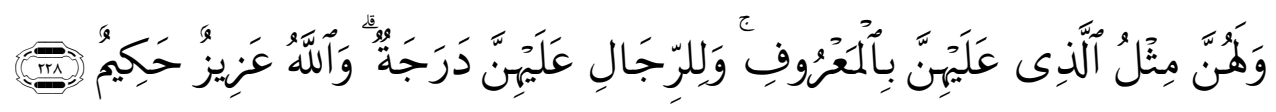

Artinya: "Dan mereka (para perempuan) mempunyai hak seimbang dengan kewajibannya menurut cara yang patut, tetapi laki-laki memiliki derajat yang lebih di antara mereka".

Dari kedua tanda yang disebutkan di atas, lebih memberikan posisi yang bagus seorang suami. Maka dari itu, agar dapat meminimalisir terhadap nushūz-nya istri, haruslah memilih istri yang baik. Istri yang baik dapat dilihat dari sebuah hadis riwayat Jarir dalam kitab Ibn Kathsïr dijelaskan yaitu: ${ }^{27}$

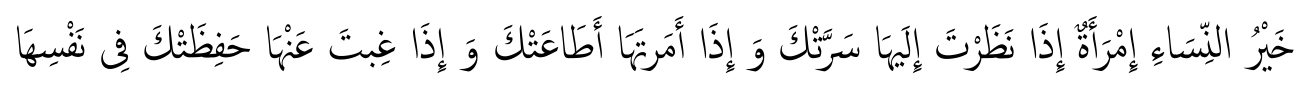
وَ مَالِهِا

Artinya: "Sebaik-baik wanita yaitu perempuan yang apabila engkau melihatnya akan menyenangkan, dan bila engkau perintah, akan mentaati perintahmu, dan bila engkau berada di belakangnya (tidak hadir), maka ia akan menjaga dirinya dan hartamu".

Dalam riwayat lain, yang diriwayatkan Imam Ahmad Ibn Abdurrahman Ibn 'Auf bahwa Rasulullah SAW, bersabda:

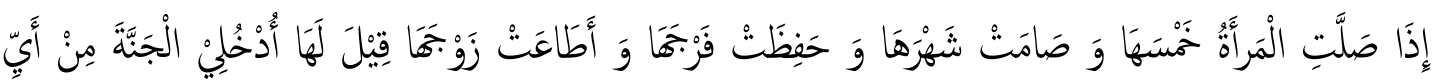

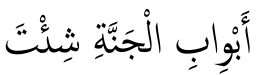

${ }^{25}$ M. 'Ali as-Ṣābuni, Șafwah al-Tafāsīir: Tafsīir al-Quran al-Karīm, juz I. (Beirut: Dār al-Fikr, 2009), 225. Lihat juga dalam Sayyid Quṭb, Tafsīi fỉ Dilāli al-Quran, Jil. II. (Beirut: Dār Syurūq, t.th), 654.

${ }^{26}$ Wahbah Zuhaili, at-Tafsiri al-Munīr, fi al- 'Aqīdah wa as-Sharī'ati wa al-Manhaj, Juz I, 58.

${ }^{27}$ Ismāil Ibn Kathsìr, Tafsir al-Quran al-Ađ̛̣im (Beirut: Dār al-Kutūb al-Miṣriyah, 2000), 22-23. 
Artinya: "Jika seorang wanita telah melaksanakan sembahyang lima waktunya (istiqamah), berpuasa pada bulannya (ramadhan), menjaga kehormatannya, dan menaati suaminya, maka dikatakan kepada mereka di hari kiamat kelak, "masuk ke dalam surga dan dari pintu manapun yang engkau suka."

Mengingat kembali makna nushūz yaitu meninggalkan kewajiban dalam keluarga (suami-istri). Nushüz dari pihak istri seperti meninggalkan rumah tanpa seizin suami, bersikap sombong terhadap suaminya, melanggar perintahnya, atau bahkan membencinya. Padahal Allah telah mewajibkan kepada istri agar menaati suami, dan haram jika mendurhakai. ${ }^{28}$

Dalam menyikapi istri yang nushüz al-Quran memberikan jalan keluar atau cara penyelesaian yaitu, pertama (فغظوهن), menasehati. Kedua (و اهجروهن في المضاجع), pisah tempat tidur. Ketiga (و اضربوهن), pukullah mereka. Dari ketiga cara itu, penulis mengambil dua tokoh mufasir yaitu Wahbah Zuhaili dan M. Quraish Shihab untuk memberikan penjelasan lebih lanjut terhadap jawaban jika ada istri yang nushüz.

Wahbah Zuhaili menjelaskan bahwa suami berhak untuk memukul istrinya, asal tidak sampai pada melukai. Pendapat tersebut tercermin dalam pernyataannya di bawah ini:

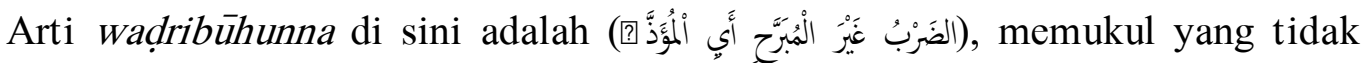
menyakitkan. Caranya adalah memukul dengan tangan ke pundaknya tiga kali, atau memukulnya dengan alat siwak, atau ranting pohon, karena tujuan dari pukulan itu sendiri adalah untuk islah, bukan yang lainnya. Bahkan apabila suami tersebut melampaui batas dalam memukul istrinya, sehingga istrinya terluka maka yang bersangkutan dikenakan denda. Sebagaimana dikenakannya denda bagi seorang guru yang memukul muridnya hingga luka, sekalipun yang diajarkannya adalah ilmu al-Quran dan etika. Kesimpulannya, pemukulan terhadap istri diperbolehkan akan tetapi dengan syarat tidak sampai melukai. ${ }^{29}$

Pendapat ini didukung mufasir klasik dan pertengahan, seperti al-Qurțūbi juga

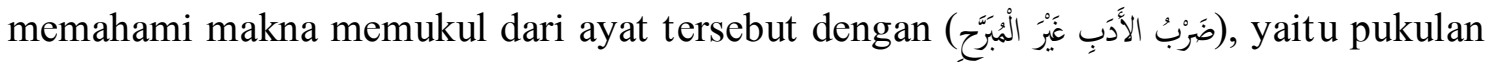
yang mendidik bukan bermakna pukulan yang menyakiti. ${ }^{30}$ Ibn Jarir at-Tabari juga

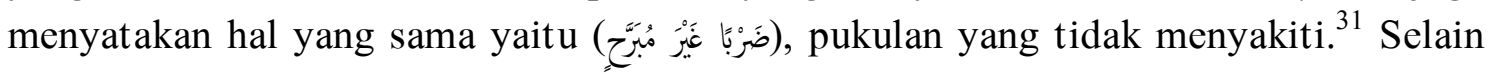

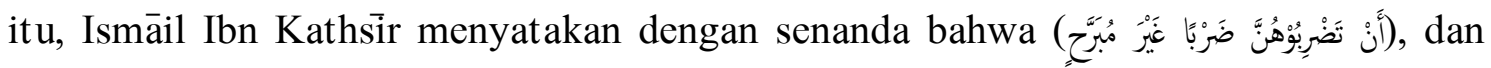
hendaklan kalian memukul mereka tanpa melukai. Pendapat ini juga diperkuat dengan hadis riwayat Muslim dari Jabir bahwa Nabi Muhammad SAW, bersabda: ${ }^{32}$

\footnotetext{
${ }^{28}$ Ismāil Ibn Kathsīi, Tafsīr al-Quran al-Aḍim, 23-24.

${ }^{29}$ Wahbah Zuhaili, Al-Tafsìr al-Muniri, juz III. 59.

${ }^{30}$ Abdullah Muhammad Ibn Ahmad al-Anșāir al-Qurțubi, Tafsìir al-Qurțūbi, (Beirut: Dār al-Kutūb al-Ilmiyah, 2010), 110.

${ }^{31}$ Abi Ja'far Muhammad Ibn Jarir at-Ṭabari, Tafsir at-Tabari Jamīul Bayān 'an Ta'wīl ayi al-Quran, 709.

${ }^{32}$ Ismāil Ibn Kathsīir, Tafsir al-Quran al-Ađ̛̣im. 26. Terdapat juga dalam Ahmad Ibn 'Ali ar-Rāzi alJașṣaș, Ahkāmu al-Quran, Jil. II. (Beirut: Dār al-Kutūb 'Ilmiyah, 2012), 189.
} 


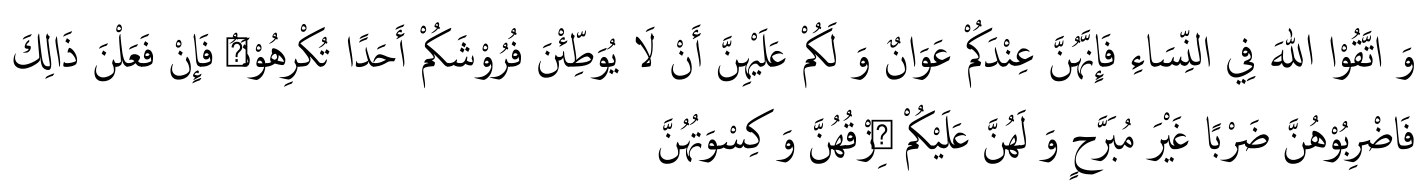

Dari hadith ini dijelaskan bahwa seorang istri yang sudah berkeluarga merupakan tanggung jawab dari suami. Maka dari itu, hendaklah dalam keluarga itu takut kepada Allah, dalam artian menjalani kehidupan keluarga sesuai dengan syariat yang telah ada. Karena bagi suami, apabila mendapati istrinya sedang nushüz, maka solusi yang telah diberikan al-Quran hendaklah dilaksanakan dengan baik, mulai dari menasihati, pisah ranjang, dan bahkan memukulnya. Pada solusi yang terakhir ini, banyak mufassir menjelaskan bahwa pukulan tersebut hendaklah tidak menyakiti fisik atau batin istri, karena semua yang ada pada istri merupakan tanggungan suami, mulai dari mahar saat nikah, nafkah hidup bahkan pakaiannya.

Lain halnya dengan M. Quraish Shihab dalam menafsirkan kalimat waḍibūhunna, banyak mengutip pendapat para ulama klasik, dan kontemporer. Dalam uraiannya yang panjang, hanya mengutip pendapat ulama lain, terutama para mufasir dari Mesir. Contohnya, dalam menafsirkan kalimat waḍribūhunna, M. Quraish Shihab hampir mengutip semua pendapat Ibn 'Ashur. Berikut adalah penafsiran yang dikemukan M. Quraish Shihab:

Betapapun kalau ayat ini (QS. An-Nisā [4] : 34), dipahami sebagai izin memukul istri bagi suami, maka harus dikaitkan dengan hadis-hadis Nabi Muhammad SAW di atas, yang mensyaratkan tidak mencederainya, tidak juga pukulan itu ditujukan kepada kalangan yang menilai pemukulan sebagai suatu penghinaan atau tindakan yang tidak terhormat. Agaknya untuk masa kini, dan dikalangan keluarga terpelajar, pemukulan bukan lagi satu cara yang tepat, karena itu tulis Muhammad Thahir Ibn 'Ashur, "Pemerintah jika mengetahui bahwa suami tidak dapat menempatkan sanksi-sanksi agama ini ditempatnya yang semestinya dan tidak mengetahui batas-batas yang wajar, maka dibenarkan bagi pemerintah, untuk menghentikan sanksi ini dan mengumumkan bahwa siapa yang memukul istrinya, maka dia akan dijatuhi hukuman. Semua ini bertujuan agar tidak berkembang luas tindakan-tindakan yang merugikan istri, khususnya dikalangan mereka yang tidak memiliki moral. ${ }^{33}$

Penafsiran yang dilakukan oleh M. Quraish Shihab, disesuaikan dengan konsep kepemimpinan yang berubah sesuai konteks perkembangan yang ada di masyarakat. Perintah daraba dari ayat tersebut diartikan memukul ketika kedudukan laki-laki sebagai pemimpin. Tetapi ketika zaman sudah berubah, maka teks qawwām tidak diartikan lagi sebagai pemimpin, namun lebih pada pengertian kemitraan, atau dengan kata lain hubungan suami istri lebih sejajar (equal). Sehingga istilah daraba dengan makna memukul sudah tidak etis pada masa sekarang. Cukup dengan memberikan isyarat akan kesalahan istri yang tidak disenangi.

\footnotetext{
${ }^{33}$ M. Quraish Shihab, Tafsir Al-Misbah: 412.
} 
Pendapat ini seirama dengan pendapat Ratna Bantara Munti, dalam Bukunya, Respon Islam Atas Pembakuan Peran Perempuan yang menyatakan, "pelaksanaan konsep daraba dalam ayat ini tidak lagi dengan memukul secara fisik, akan tetapi cukup dengan memberi isyarat yang sesuai berupa ungkapan yang berbunyi, "Orang bodoh, dan budak memukul dengan tongkat, sedang orang merdeka memukul dengan isyarat." Jadi, untuk tidak mencederai istri hendaklah dilakukan dengan isyarat perkataan atau teguran dan dibuktikan dengan perbuatan (pisah ranjang). ${ }^{34}$

Secara eksplisit, ayat ini memberikan izin kepada suami untuk memukul istri sebagai alternatif terakhir dari beberapa cara untuk menghentikan istri yang nushüZ terhadap suaminya. Kalimat wadribühunna, yang dimaknai memukul dengan tangan, hal ini dikarenakan masih melihat pada tafsir-tafsir klasik yang masih membolehkan pemukulan terhadap istri. Semua itu dikarenakan istri masih masuk dalam kasta kedua (second class), dan para ulama pada masa itu tidak mau keluar dari pernyataan tekstual terhadap makna daraba tersebut.

Sebenarnya banyak tulisan yang mendukung dan mengkritisi pemukulan terhadap istri. Dalam jurnal yang mendukung misalnya berjudul, Kekerasan dalam Rumah Tangga Persepektif Fikih, yang ditulis oleh Laa Jamaa, dalam jurnal Ahkam, Vol. XIII, No. 1, pada Januari, 2013. Tulisan tersebut masih membenarkan kata daraba dengan makna memukul sebagai kekerasan fisik terhadap perempuan tetapi dengan cara yang beradab bukan cara yang biadab. ${ }^{35}$ Sedangkan dalam jurnal yang mengkritisi misalnya Pembacaan Ulang Terhadap Wadhribuhunna dalam Surat an-Nisa' ayat 34, yang ditulis Syarial Dedi, dalam jurnal Istinbath (jurnal hukum dan ekonomi Islam), Vol. 17, No. 2, pada Desember, 2018 yang memberikan penjelasan tentang Penghapusan Kekerasan dalam Rumah Tangga yang tertuang dalam UU No. 23 Pasal 1 ayat 1 yang berbunyi: "kekerasan dalam rumah tangga adalah perbuatan setiap seseorang terhadap orang lain, utamanya perempuan yang menyebabkan kesengsaraan secara fisik, psikologi, dan seksual, atau bahkan penelantaran dalam rumah tangga termasuk ancaman yang merampas kemerdekaan dalam rumah tangga. ${ }^{36}$

Al-Quran memberikan solusi alternatif untuk mengatasi pembangkangan istri terhadap suami dalam konteks sosial saat ini. Solusi tersebut dapat dipandang sebagai langkah progresif yang mengarah pada perwujudan rekonsiliasi tanpa adanya kekerasan dalam keluarga. Sesungguhnya al-Quran menghendaki penghentian cara-cara kekerasan untuk mengatasi nush $\bar{u} z$ istri. Nabi Muhammad SAW, sendiri memberikan contoh penghentian itu dilakukan dengan memberikan kepada isrti hak membalas. Tetapi, tampaknya al-Quran melihat penghentian itu tidak efektif jika dilakukan seketika, "Aku menghendaki sesuatu (balas memukul), tetapi Allah SWT menghendaki

\footnotetext{
${ }^{34}$ Ratna Bantara Munti, Respon Islam atas Pembakuan Peran Perempuan, (Jakarta: LBH-APIK, 2005), 43.

${ }^{35}$ Laa Jamaa, "Kekerasan dalam Rumah Tangga Persepektif Fikih”, Jurnal Ahkam, Vol. XIII, No. 1 (Januari, 2013), 77.

${ }^{36}$ Syarial Dedi, "Pembacaan Ulang Terhadap Wadhribuhunna dalam Surat an-Nisa' ayat 34," Jurnal Istinbath (Jurnal Hukum dan Ekonomi Islam), Vol. 17, No. 2 (Desember, 2018), 446-447.
} 
yang lain", kata Nabi. "Di sini, kita melihat bagaimana al-Quran, sekali lagi memberikan kepada kita wacana teori gradualisasi dan evolusi untuk reformasi kultural yang akut". ${ }^{37}$ Maka dari itu, makna dari wadribūhunna lebih tegas dan tepat memukul dengan isyarat. Karena keadaan kontemporer lebih menghargai keadaan tanpa kekerasan, dan lebih setara serta relevan dengan kesetaraan gender.

Sebenarnya memukul istri tidak dilarang dalam syariat, dalam artian diperbolehkan memukul dengan tujuan agar kejelekan yang ada pada diri istri tersebut dapat hilang. Karena pemukulan ketika itu dijadikan sebagai wasilah untuk mencapai perbaikan pribadi istri yang merupakan tujuan agar terhindar dari perpecahan dalam rumah tangga.

Perlu disadari dalam implikasinya, bahwa penerapan konsep penafsiran yang dilakukan oleh kedua mufassir tersebut adalah untuk menampilkan iṣlah (kemashlahatan) yang ada dalam keluarga agar tidak identik dengan kekerasan dalam rumah tangga. Kebijakan yang demikian telah disesuaikan dengan daerah dan keadaan dimana tafsir itu akan dipakai sebagai sebuah dasar keilmuan dalam Islam.

Wahbah Zuhaili daerah sebaran tafsirnya negara Mesir, yang identik dengan madzhab fikih Hanafi, yang cenderung pada aspek nas. Sedangkan M. Quraish Shihab yang mayoritas pembaca tafsirnya orang asli Indonesia, identik dengan madzhab fikih Syafii yang cenderung lebih banyak kepada aspek konteks. Sehingga salah satu yang menjadi pembeda dari kedua mufassir tersebut adalah madzhab fikih. Indonesia juga lebih mengedepankan kesetaraan dalam hukum sosial yang berbeda dengan Mesir yang lebih mengedepankan hukum Islam. Sehingga kebudayan yang ada pada masingmasing negara dimana tafsir tersebut dijadikan rujukan oleh mayoritas penduduknya juga mempengaruhi hasil dari suatu penafsiran. Maka dari itu, tidak heran jika Wahbah Zuhaili masih menekankan memukul dengan alasan kebahasaaan, dan dalil naṣ sebagai dasar dengan harapan tidak melukai istri. Sedangkan M. Quraish Shihab sudah menggeser pemaknaannya dari memukul menjadi menggunakan isyarat, yang tidak lain karena adanya perbedaan dalam suatu kehidupan masyarakat antara negara Mesir dengan Indonesia yang lebih mengedepankan tatakrama.

Dari uraian di atas, dapat dicantumkan dalam bentuk tabel.

Tabel. 1

Komparasi Penafsiran Wahbah Zuhaili dan M. Quraish Shihab

\begin{tabular}{|c|c|c|}
\hline No. & Wahbah Zuhaili & M. Quraish Shihab \\
\hline 1. & ضربا غير مبرح إن لم يرجعن بالهجران & $\begin{array}{l}\text { Jika ayat nushüz diterapkan sesuai nas al- } \\
\text { Quran, maka sebelum memukul harus } \\
\text { mempertimbangkan hadis-hadis Nabi yang } \\
\text { berkaitan dengan kemuliaan perempuan. }\end{array}$ \\
\hline
\end{tabular}

\footnotetext{
${ }^{37}$ Muhammad Husein, Islam Agama Yang Ramah Bagi Perempuan, (Yogyakarta: LkiS, 2004), 255.
} 


\begin{tabular}{|c|c|c|}
\hline 2. & 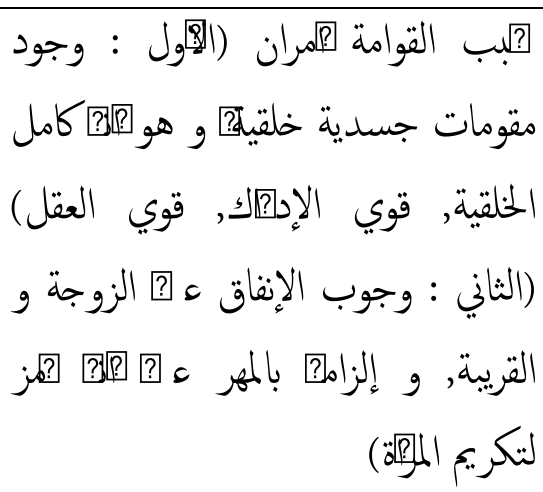 & $\begin{array}{l}\text { Perintah memukul dibolehkan jika laki-laki } \\
\text { sebagai pemimpin. Akan tetapi, kemajuan } \\
\text { zaman berubah sehingga teks (قوام) tidak } \\
\text { diartikan sebagai pemimpin, tetapi lebih tepat } \\
\text { kepada kemitraan (equal). }\end{array}$ \\
\hline 3. & 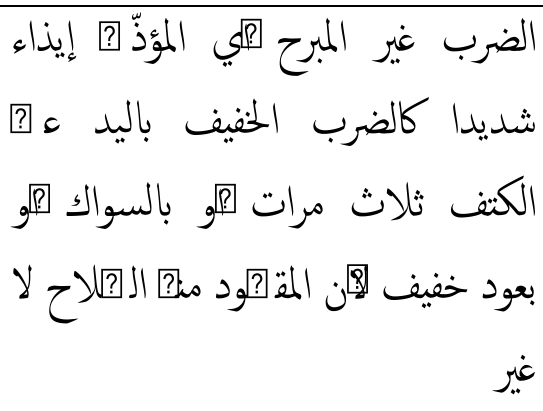 & $\begin{array}{l}\text { Al-Quran memberikan solusi terhdap istri yang } \\
\text { nushüz pada ayat di atas. Akan tetapi solusi } \\
\text { terakhir yaitu al-Quran sebagai petunjuk dan } \\
\text { pedoman sepanjang masa mengajarkan } \\
\text { bagaimana cara memposisikan perempuan } \\
\text { (rekonsiliasi). }\end{array}$ \\
\hline 4. & $\begin{array}{l}\text { Berbedanya budaya } \\
\text { kehidupan, dan madzhab fikih } \\
\text { (Mesir-Imam Hanafi), serta } \\
\text { kentalnya penerapan hukum } \\
\text { Islam dengan al-Quran dan } \\
\text { hadis sebagai dasar dalam } \\
\text { kehidupan sehari-hari. }\end{array}$ & $\begin{array}{l}\text { Berbedanya budaya kehidupan, dan madzhab } \\
\text { fikih (Indonesia-Imam Syafii) serta pentingnya } \\
\text { kesetaraan hukum dalam kehidupan sosial di } \\
\text { Indonesia yang lebih mengedepankan } \\
\text { tatakrama dan sopan santun. }\end{array}$ \\
\hline
\end{tabular}

\section{Penutup}

Dari penjelasan di atas dapat disimpulkan bahwa pendapat antara Wahbah Zuhaili dan M. Quraish Shihab memiliki perbedaan yang tipis dalam hasil penafsirannya mengenai QS. An-Nisā [4] : 34 terhadap lafadz (و اضربوهن), yaitu budaya yang ada pada negara masing-masing terapan tafsirnya, yang intinya sama-sama menerapkan konsep perdamaian, kebaikan, (ișlah) dalam keluarga yang berbeda pandangan. Akan tetapi, semua itu sudah cukup dapat menambah pengetahuan dan pemahaman mengenai hasil tafsir dari keduanya.

Pendapat Wahbah Zuhaili yang banyak didukung oleh tafsir klasik dengan madzhab fikih Hanafi, menjelaskan bahwa seorang laki-laki dalam menyelesaikan masalah yang ada dalam keluarga hendaklah dilakukan dengan cara yang sesuai syariat agama, yaitu memberikan nasihat terhadap istri yang nushüz, berpisah dalam tempat tidur dengan tujuan istri yang nushüz tadi dapat berubah pikiran, dan yang terakhir hendaklah menegurnya dengan sebuah pukulan. Akan tetapi dalam memukul hendaklah tidak mencederai perempuan, adakalanya dengan memukul pundaknya tiga kali, dan 
memukulnya itu dengan ranting kayu siwak atau ranting pohon yang kecil, karena apabila sampai mencederai maka akan berlaku hukum Qișās.

Sedangkan penafsiran M. Quraish Shihab lebih ditekankan kepada konsep kesetaraan dalam bermasyarakat. Konsep yang diterapkan oleh M. Quraish Shihab dalam tafsirnya lebih menekankan kesetaraan dengan memberikan makna pada lafad Qawwām dengan makna kesetaraan antara laki-laki dengan perempuan (equal). Selanjutnya juga dijelaskan bahwa M. Quraish Shihab lebih menggunakan metode yang kedua, yaitu dengan cara pisah ranjang, dalam memaknai pada metode yang ketiga ini dengan halus yaitu menggunakan bahasa isyarat. Pendapat ini didukung oleh Ratna Bantara Munti dengan mengatakan bahwa alangkah baiknya jika laki-laki menghadapi istri yang nushüz dengan cara menasihati, dan pisah ranjang, sedang yang ketiga pada ide memukul lebih ditekankan dengan memberikan isyarat.

Dari kesemua perbedaan tipis yang ada pada kedua mufassir tersebut memiliki tujuan yang utama, yaitu menjaga keutuhan dalam keluarga dengan mengedepankan perdamaian, kebaikan (ișlāh). Namun, jika diteliti lebih mendalam akar perbedaan dari keduanya adalah bedanya budaya di antara masing-masing negara, yaitu antara Mesir dan Indonesia. Mesir yang lebih mengedepankan syariat yang ada dalam menjalankan kehidupan, sedangkan Indonesia lebih mengutamakan tatakrama, sopan santun dalam bersikap dan bermasyarakat.

\section{DAFTAR PUSTAKA}

Abdullah, Abdul Ghani, Pengantar Kompilasi Hukum Islam Dalam Tata Hukum Indonesia, Jakarta: Gema Insan Press, 1994.

Ahmad al-Wahidi, Imam Abi Hasan Ali Ibn, Asbāb Nuzūl al-Quran, Libanon: Dār-alKutūb al-Ilmiyah.

Dedi, Syarial, "Pembacaan Ulang Terhadap Wadhribuhunna dalam Surat an-Nisa' ayat 34," Jurnal Istinbath (Jurnal Hukum dan Ekonomi Islam), Vol. 17, No. 2 Desember, 2018.

Departemen Agama RI, Al-Quran dan Terjemah Bahasa Indonesia, Kudus: Menara Kudus, 2006.

Ghafur, Waryono Abdul, Menyingkap Rahasia al-Quran, Yogyakarta: eLSAQ Press, 2009.

Husein, Muhammad, Islam Agama yang Ramah Bagi Perempuan, Yogyakarta: LkiS, 2004.

Jamaa, Laa, "Kekerasan dalam Rumah Tangga Persepektif Fikih", Jurnal Ahkam, Vol. XIII, No. 1 Januari, 2013.

Jarìr at-Ṭabari, Abi Ja'far Muhammad Ibn, Tafsìr at-Tabari Jamīul Bayān 'an Ta'wīli àyi al-Quran, Kairo: Dār-Hijr, 2001. 
Kathīr, Ismāil Ibn, Tafsìir al-Quran al- 'Adzim, Makkah: Dār al-Kutub al-Mișriyah. , Jamī al-Masānid wa as-Sunan, Juz XIII. Beirut: Dār Khudr, 1998.

Kementerian Agama RI, al-Quran dan Tafsirnya, Jil. II. Jakarta: Widya Cahaya, 2011.

Kyai Demak, Abdurrahman, Kepemimpinan Wanita dalam Islam dalam al-Quran dan Isu Kontemporer, Yogyakarta: elSAQ Press, 2011.

Munti, Ratna Bantara, Respon Islam Atas Pembakuan Peran Perempuan, Jakarta: LBH-APIK, 2005.

Mulia, Siti Musdah, Kemuliaan Perempuan Dalam Islam, Jakarta: LBH-APIK, 2014.

Mustaqim, Abdul, Madzahibut Tafsir Peta Metodologi Penafsiran al-Quran Periode Klasik Hingga Kontemporer, Yogyakarta: Nun Pustaka, 2003.

Muslikhati, Feminisme dan Pemberdayaan Perempuan dalam Timbangan Islam, Jakarta: Gema Insani, 2004.

Mustaqim, Abdul, Dinamika Sejarah Tafsir al-Quran: Studi Aliran-Aliran Tafsir dari Periode Klasik, Pertengahan, hingga Modern-Kontemporer, Yogyakarta: Pondok Pesantren LSQ ar-Rahmah, 2012.

Sābiq, Sayyid, Fiqh as-Sunnah, Jil. II, Madinah: al-Fath li I'lāmi al-'Arabi, 1992.

Shihab, M. Quraish, Tafsir Al-Misbah: Pesan, Kesan dan Keserasian Al-Quran, vol II. Jakarta: Lentera Hati, 2002.

, Wawasan al-Quran: Tafsir Tematik Atas Berbagai Persoalan Umat, Bandung: Penerbit Mizan, 2013.

Zuhaili, Wahbah, at-Tafsir al-Munïr fi al-'Aqidah wa as-Syrari'ati wa al-Manhaj, Juz. I. Damaskus, Dār al-Fikr, 2009. , at-Tafsir al-Munir fi al-'Aqidah wa as-Syrari'ati wa al-Manhaj, Juz. III. Damaskus, Dār al-Fikr, 2009.

Al-Husain bin Muhammad, Abu al-Qāsim. Al-Mufradāt fi Gharīb al-Quran, Nazar Musthafa al-Bāz.

al-Jașṣaṣ, Ahmad Ibn 'Ali ar-Razi, Ahkāmu al-Quran, Jil. II. Beirut: Dār al-Kutūb 'Ilmiyah, 2012.

As-Ṣābuni, M. 'Ali, Shafwah al-Tafāsìr Tafsìr al-Quran al-Karìm, juz I, Beirut: Dār alFikr. 2009.

As-Suyūti, Jalaluddin. ad-Durru al-Manthsūr fi Tafsìr bi al-Ma'thūr, Juz II, Riyadh: Dār 'Alim al-Kutub, 2015. 